\title{
POST-THERMAL TREATMENT OF ORIENTED STRANDBOARD (OSB) MADE FROM CYPRESS (CUPRESSUS GLAUCA LAM.)
}

\author{
E. Y.A. Okino' , D. E. Teixeira², C. H. S. Del Menezzi ${ }^{3}$
}

\begin{abstract}
The objective of this research was to determine the physical and mechanical properties of oriented strandboard (OSB) using strands of Cupressus glauca Lam., before and after a thermal treatment, as well as to evaluate the susceptibility of the boards to fungi attack. Boards with nominal density of 0.70 $\mathrm{g} / \mathrm{cm}^{3}$ were produced with $5 \%$ and $8 \%$ of urea-formaldehyde (UF) resin. Physical and mechanical properties were evaluated according to ASTM D 1037 (1991) standard and compared with CSA O437.0 and ANSI A.208.1 standards. All mechanical properties were higher than those values required by both standards, except the modulus of elasticity in parallel axis. The thermal treatment slightly reduced the modulus of elasticity and stress at proportional limit, both in perpendicular axis, however improved significantly dimensional stability. Dimensional stability of the treated OSB was improved at the lower resin level but did not reach the maximum value required by the Canadian standard. Biological assay showed that heat-treated cypress OSB exposed to P. sanguineus reduced mass loss from $39 \%$ to $50 \%$, while for G. trabeum the reduction was from $40 \%$ to $49 \%$. Post thermal treatment of manufactured $\operatorname{OSB}\left(190^{\circ} \mathrm{C}, 720 \mathrm{~s}\right)$ can be the recommended method to reduce the hygroscopicity without great effect on mechanical properties and to protect panels against these fungi.
\end{abstract}

Keywords: oriented strandboard, material properties, thermal treatment, biodeterioration.

\section{INTRODUCTION}

Plywood and oriented strandboard (OSB) panels are very similar in the conception of reducing the dimensional stability and anisotropy of the wood, but raw material, manufacturing process and mechanical properties are very different. The disadvantage of OSB compared to plywood is the higher dimensional instability. To improve this property it is necessary to reduce the water adsorption of the wood and release the stress imposed during the hot-pressing process. Some studies have evaluated a method which can do this in an one-way step: the thermal treatment applied after the consolidation of the panel.

One of the first studies to evaluate this kind of treatment was conducted by Roffael and Rauch (1973). They evaluated di-isocyanate bonded particleboards exposed to $200^{\circ} \mathrm{C}$ for 15 to 60 minutes and the results showed a decrease in thickness swelling (TS) and water absorption (WA). The modulus of rupture (MOR) was reduced up to $20 \%$. Shen (1974) exposed urea-formaldehyde bonded panels from 260 to $343^{\circ} \mathrm{C}$ during two to four seconds pressed from 200 to 600 psi. No significant change in MOR and shear strength was observed. Hsu et al. (1989) heat-treated phenol-formaldehyde bonded waferboard at $240^{\circ} \mathrm{C}$ during $2.67,4.16$ and 10.50 minutes and verified an enhancement in TS and a slightly deleterious effect on the MOR. They also concluded that stiffness is more affected by thermal treatment than strength. Suchsland and Xu (1991) also studied yellow-poplar flakeboard under $232^{\circ} \mathrm{C}$

\footnotetext{
${ }^{1}$ Chemistry, M.Sc., Laboratório de Produtos Florestais. IBAMA. Brasília-DF. Brasil.

${ }^{2}$ Forestry Engineer, Ph.D., Laboratório de Produtos Florestais. IBAMA. Brasília-DF. Brasil.

${ }^{3}$ Forestry Engineer, Ph.D., Departamento de Engenharia Florestal. Universidade de Brasília. Brasília-DF. Brasil

Corresponding author: esmeralda.okino@ibama.gov.br

Received: 02.04. 2007. Accepted: 27.07. 2007.
} 
during 15 minutes and concluded that TS value was clearly diminished. It can be observed that there exists no work concerning the utilization of thermal treatment on UF bonded wood panels, probably because this type of resin can be degraded under these conditions.

On the other hand, it is very well known that thermal treatment has a deleterious effect on mechanical properties of wood. According to Bengtsson et al. (2002), the heat-treatment decreases the strength and the stiffness of the wood. However, the extent of loss may vary either by the heat-treatment schedule or the wood species. Softwoods have shown larger reductions in strength than hardwoods. Usually, the bending and tensile strength of heat-treated material is reported to drop between $10 \%$ and $30 \%$. Goroyias and Hale (2002) studied the effect of heat treatment from $200^{\circ} \mathrm{C}$ to $260^{\circ} \mathrm{C}$ with increments of $10^{\circ} \mathrm{C}$ during 20 minutes on the mechanical and physical properties of strands. They concluded that high temperature treatments resulted in significant reductions in thickness swelling of wood strands as well as in modulus of rupture and modulus of elasticity by $20 \%$.

A very promising method to improve dimensional stability has been studied in Brazil since 2001. It is a kind of post-thermal treatment where panel is re-pressed and heated, with pressure enough to ensure contact between the panel and the press platens. Recently, Del Menezzi and Tomaselli (2006) employed this treatment $\left(250^{\circ} \mathrm{C}, 240 \mathrm{~s}, 420 \mathrm{~s}, 600 \mathrm{~s}\right)$ in a single layered OSB from Pinus taeda, with $0.8 \mathrm{~g} / \mathrm{cm}^{3}$ nominal density and $8 \%$ of phenol-formaldehyde resin, and observed reduction in TS, equilibrium moisture content (EMC) and permanent thickness swelling (PTS). Del Menezzi (2004) used this same method to treat commercial pine OSB bonded with phenol-formaldehyde in surface layer and di-isocyanate in the core layer at $190^{\circ} \mathrm{C}$ and $220^{\circ} \mathrm{C}$ during $720 \mathrm{~s}, 960 \mathrm{~s}$, and $1200 \mathrm{~s}$.

Thickness swelling decreased in 39\% and 25\%, after 2 and $24 \mathrm{~h}$ of water immersion, respectively, while WA was reduced in average $31 \%$ and $17 \%$, respectively. There was a decrease in average of $5.9 \%$ in mechanical properties, but this was not statistically significant. This relative low impact on mechanical properties could be attributed to as a strategy on thermal treatment, such as fast heating conduction and short time of treatment. However, they observed that the total amount of hemicelluloses was reduced by $20 \%$ for treated OSB $\left(220^{\circ} \mathrm{C}, 1200 \mathrm{~s}\right)$, so panels became less hygroscopic. Thus, if hemicelluloses are degraded, some improvement can be expected on the resistance against fungi decay because it is the main wood polymer source of these organisms. In fact, several studies have demonstrated that the thermal treatment is effective in enhancing this property. According to Yang et al. (2000), southern yellow pine OSB were exposed to 14 brown-rot and 8 white-rot decay fungi. In general, brown-rot fungi degraded OSB to a greater extent than did white-rot fungi. The rate of degradation was the same as that of solid wood, but higher weight loss was obtained with OSB.

In this context, the cypress species was chosen to manufacture OSB with the purpose of evaluating its potential as raw material for the panel industry. The Laboratório de Produtos Florestais - LPF, a federal government laboratory has sponsored researches using cypress to generate basic data (Okino et al., 2006), technological properties of cement-bonded particleboard (Okino et al., 2005) and acetylated particleboard (Okino et al., 2004). It was also planned other studies about OSB manufacturing as well as technical feasibility evaluation of the thermal post-treatment for panels made from other woods that have been proved to be suitable for reconstituted composites. The objective of this research was to manufacture cypress OSB and expose them to post press-heat treatment to determine the physical/ mechanical properties and susceptibility of the boards to different fungi of the treated and untreated control specimens. 


\section{MATERIAL AND METHODS}

\section{Wood Material}

Logs of cypress Cupressus glauca Lam., approximately 17-year-old, were collected in Brasília, Brazil, and processed into blocks of 20x100x190 mm. This material was converted into strands in a rotative disc flaker. The strands were sieved in a mechanical screen device and only those passing through a $24 \mathrm{~mm}$ aperture and retained on a $8 \mathrm{~mm}$ sieve were used. These strands were dried in an electrical oven at $105^{\circ} \mathrm{C}$ to reach constant humidity content around $4 \%$. The final dimension of the strands was approximately $0.7 \times 20 \times 70 \mathrm{~mm}(t \times w \times l)$.

\section{OSB Manufacturing}

The 13-mm thick mats were hand-formed and pressed on manually controlled hydraulic steamheated press platens at $175^{\circ} \mathrm{C}$ and $4.0 \mathrm{MPa}$ of pressure for 8 minutes. The boards were manufactured with two resin levels (5\% and $8 \%$ ) based on the oven-dry weight of the strands. Ammonium chloride at 5\% was used as a catalyst and no wax was added. The UF resin (CASCAMITE PB 2346, Alba Química Ltd) was chosen to evaluate the degree of enhancement of the dimensional stability of the boards when thermal treatment was applied. It presented $66 \%$ of solid contents and the viscosity was adjusted to $267 \mathrm{mPa}$.s at $25^{\circ} \mathrm{C}$. The non-volatile content was determined according to ASTM D 149067 (1972) and the viscosity was measured with a Brookfield Viscometer Model VRF-100. The resin was sprayed using a rotary blender DRAIS FSP 80 . For each resin level, six three-layer boards with a surface/core layer ratio of 50/50 were manufactured. Each panel measured 450x450x13 mm and had a nominal target density of $0.70 \mathrm{~g} / \mathrm{cm}^{3}$. After the production the boards were room conditioned at $(65 \pm 2) \%$ and $(20 \pm 1)^{\circ} \mathrm{C}$ to reach constant weight.

\section{Thermal Treatment}

After the conditioning each board was trimmed $(430 \times 430 \mathrm{~mm})$ to eliminate low density edge and cut so as to obtain two halves $(210 \times 430 \mathrm{~mm})$. One half was thermally treated at $190^{\circ} \mathrm{C}$ during 12 minutes using a single-opening hot press while the other one remained untreated. A pressure was applied just to provide the contact between press plates and the boards' surfaces.

\section{Physical and Mechanical Properties}

Physical and mechanical properties of the treated and untreated boards were evaluated according to ASTM D1037 (1996) standard. Two specimens were cut following parallel (//) and perpendicular $(\perp)$ axis for static bending testing to determine modulus of rupture (MOR), modulus of elasticity (MOE) and stress at proportional limit (SPL), while three specimens were cut for internal bond (IB) and two for screw withdrawal $(\mathrm{SW})$ and Janka hardness $(\mathrm{JH})$. These tests were conducted using an INSTRON 1127 Universal Testing Machine. To evaluate physical properties, four samples were cut for water absorption (WA), thickness swelling (TS), apparent specific mass and moisture content (MC) tests.

\section{Biological Assay}

The laboratory decay test followed ASTM D 2017-05 (2005) standard, with twelve specimens assigned per treatment. Two brown-rot fungi (Gloeophyllum trabeum (Persoon ex Fries) Murrill, Lentinus lepideus Fries) and two white-rot fungi (Pycnoporus sanguineus (Persoon ex Fr.) Murrill e Ganoderma applanatum (Persoon ex Wallroth) Patouillard) were tested and maintained in the Laboratório de Produtos Florestais (LPF). Two woody support samples (Pinus sp. and Cecropia sp.) were used with dimensions 3.0x29x35 mm to provide the initial growth of the fungi. The flasks were autoclaved at $121^{\circ} \mathrm{C}$ during 60 minutes and the incubator room condition was $(26.7 \pm 1.1)^{\circ} \mathrm{C}$ and relative humidity $(70 \pm 4) \%$. Twelve replicates per treatment measuring $25 \times 25 \mathrm{~mm}$ by the thickness of the boards were tested. The percentage of weight loss (WL) was calculated for each test specimen from the conditioned weight before and after exposure to the decay fungi for 12 weeks. The specimens were rated after testing according to the methodology described by ASTM D 2017-05 (2005). 


\section{Experimental design}

The test results were submitted to analysis of variance (ANOVA) using the SPSS 13.0 for Windows (Statistical Program for Social Science), and the comparison among treatments' means was tested using the Tukey HSD test at 5\% significance level.

\section{RESULTS AND DISCUSSION}

\section{Physical and Mechanical Properties}

The values of mechanical properties are shown in Figure 1. The MOR values in the parallel direction were 1.3 to 1.8 fold higher than the minimum value required by CSA O437.0 standard, class O-2, which is $29 \mathrm{MPa}$. The MOR values in perpendicular direction were also 2.3 to 2.8 folds higher than the minimum value required by the same class, which is $12.4 \mathrm{MPa}$. The ratios of MOR between parallel and perpendicular directions ranged from 1.5 to 1.9, showing the degree of strands alignment. Even though, there was no significant difference among the four treatments, the thermal treatment causing a decrease of $15 \%$ in the parallel MOR. This trend was also observed in the perpendicular MOE at the $8 \%$ resin level. The panel density of the four treatments was near target density and no significant difference among means was identified.

Comparing MOR values between untreated cypress OSB with $8 \%$ UF resin and aspen OSB with $3.5 \% \mathrm{PF}$ resin (Ayrilmis et al, 2005), the first showed mean values $45 \%$ higher. Compared with control $8 \%$ UF resin cypress OSB, the commercial pine sheathing and flooring OSB (Wang et al, 2004) had MOR values, in perpendicular and parallel direction, reduced by $49 \%$ and $38 \%$, respectively.

All MOE values in parallel direction were lower than the minimum required by CSA O437.0 standard, class $\mathrm{O}-2$, which is 5,500 MPa. The MOE values in the perpendicular direction were in average 1.5 and 1.7 fold higher than the standard requirement, which is 1,500 MPa. The MOE ratios between parallel and perpendicular directions ranged from 1.3 to 1.5 . 


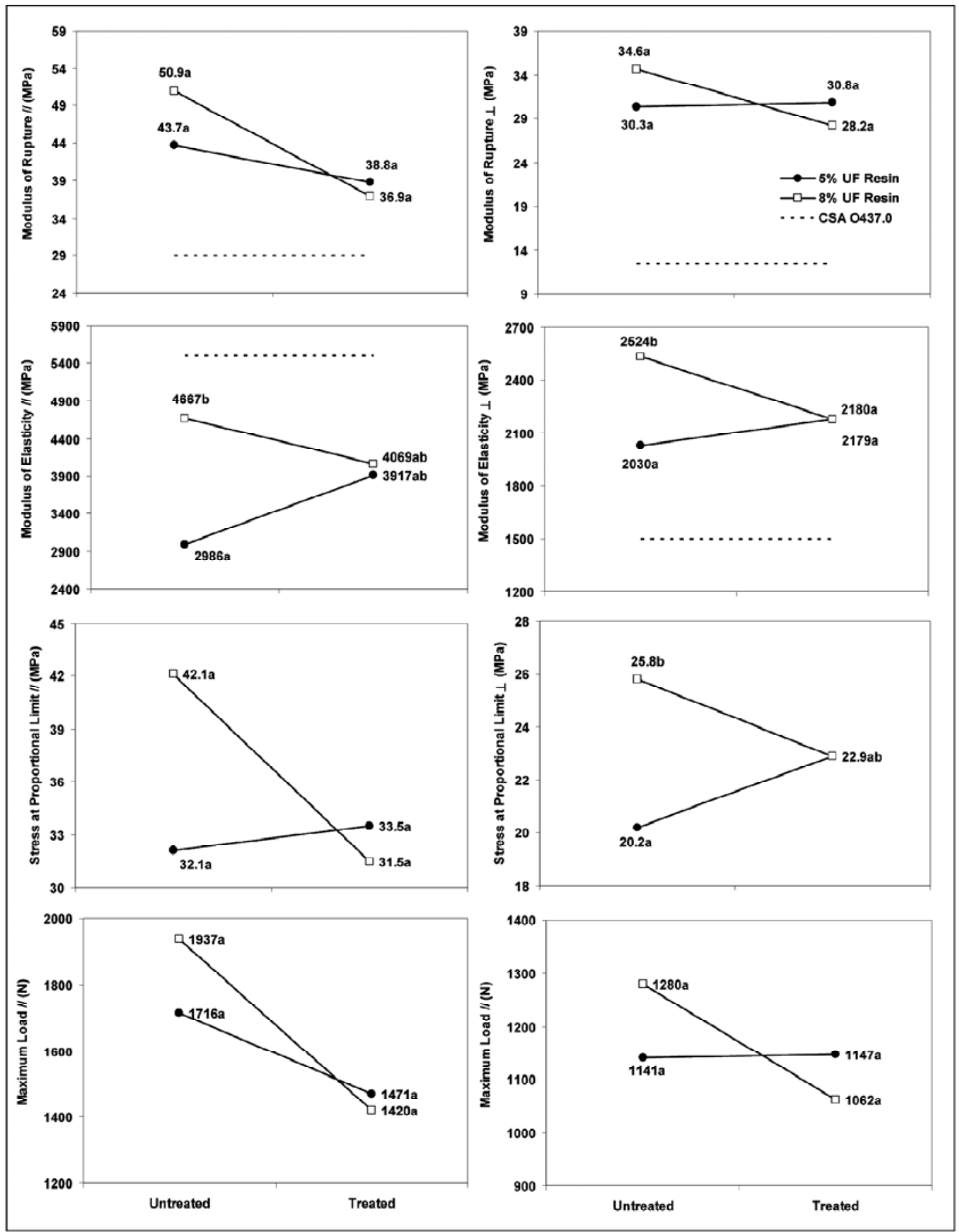

Figure 1: Static bending properties of control and thermally treated OSB made from cypress. (Values followed by a different letter are statistically different at $\alpha=0.05$, according to Tukey HSD test). 
The resin level was significant only for those panels that were not submitted to the thermal treatment. The treatment caused a decrease in the elasticity only for the panels with $8 \%$ resin in the perpendicular direction. Regarding mechanical properties, the thermal treatment did not have any effect, except on the MOE in the perpendicular direction of alignment within panels bonded with $8 \%$ resin.

Mean values of SPL in the parallel direction showed no difference among treatments, while in the perpendicular direction they showed two homogeneous groups. The treatment had no effect on this property, but the resin level had, for SLP in the perpendicular direction and only for the untreated panels. As predicted, mean values of maximum load in the parallel direction were higher than in the perpendicular direction, without any difference among treatments.

Results presented in Figure 1 show that heat-treated OSB at 5\% UF generally experienced increasing mechanical performance, except to MOR and maximum load, in parallel direction, whereas with $8 \%$ UF this trend is not shown. It might be that the secondary heat-treatment further cured the $5 \%$ UF resin and/or negatively affected the $8 \%$ UF cure.

The values of IB, SW and JH are presented in Figure 2. The IB values were higher than minimum required by CSA O437.0, class O-2, which is $0.345 \mathrm{MPa}$. In general, these values were 1.5 to 1.8 higher than the requirement, evidencing the good bonding quality of the strands. The thermal treatment did not have any effect on the IB and no difference was observed among the four treatments. Comparing the results obtained, the values observed were approximately $38 \%$ higher than those obtained by Ayrilmis et al (2005) for aspen OSB with 3.5\% PF resin. SW and JH values were 1.4 to 2.0 folds higher than those required by ANSI A.208.1 and CSA O437.0 standard, class O-2. No evidence was observed of means differences among the treatments according to the Tukey test on SW and JH.

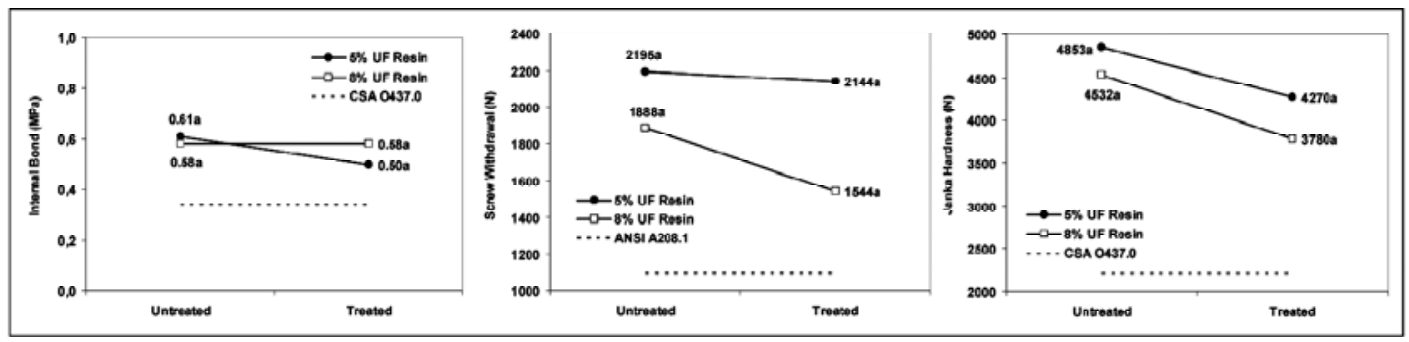

Figure 2: Internal bond, screw withdrawal and Janka hardness of control and thermally treated OSB made from cypress. (Values followed by a different letter are statistically different at $\alpha=0.05$, according to Tukey HSD test).

Based on these results there are a great potential to use cypress as an alternative reforestation species since special attention is given in the genetic improvement and also management.

The results of the physical properties are presented in Figure 3. The thickness swelling after 24 hours of water soaking exceeded the maximum value required by CSA O437.0, class O-2. The thermal treatment improved dimensional stability to a higher extent at the lower resin level. Regarding the $8 \%$ resin level, the treatment was not so efficient as to improve dimensional stability. Contrary to trends shown in Figure 1, the physical property results shown in Figure 3 seems to show that $8 \%$ UF clearly out-performed 5\% UF. This behavior could be related to the known lack of UF-water-resistance.

Present results compared with Del Menezzi and Tomaselli (2006) showed that treated laboratorymanufactured OSB were more unstable than the further, but this might be explained by the use of nonwater resistant resin and non-conventional particles. Nevertheless just one set of processing conditions 
$\left(190^{\circ} \mathrm{C}, 720 \mathrm{~s}\right)$ was studied, the best conditions found in the study by Del Menezzi (2004), both thickness swelling and water absorption decreased after the thermal treatment, showing a direct relationship between them, rather still the treatment did not attend the maximum requirement to thickness swelling after $24 \mathrm{~h}$.

Apparent specific mass ranged from 0.691 to $0.749 \mathrm{~g} / \mathrm{cm}^{3}$ and according to Tukey test it showed only one homogeneous group. Comparing apparent specific mass between control and treated OSB with $8 \%$ UF resin, the values were 0.749 and $0.702 \mathrm{~g} / \mathrm{cm}^{3}$, respectively. Secondary thermal treatment did not caused a densification of the panels, so physical and mechanical properties should not be highly changed.
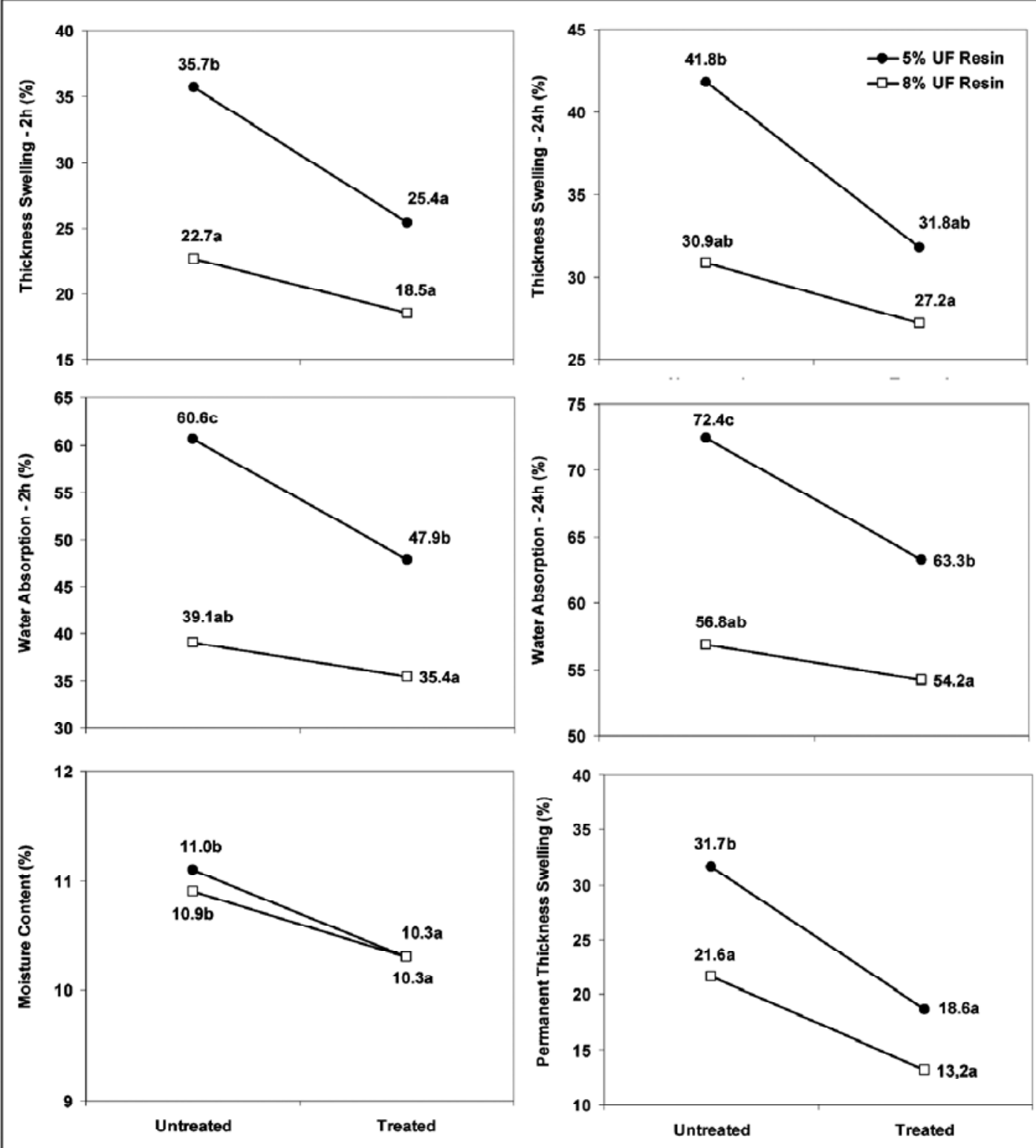

Figure 3: Physical properties of control and thermally treated OSB made from cypress. (Values followed by a different letter are statistically different at $\alpha=0.05$, according to Tukey HSD test). 
Thermal treatment resulted in improved dimensional stability of the manufactured OSB, on finding the permanent thickness swelling (PTS) or "springback", showing a reduction in average $41 \%$ to $39 \%$ in thickness when compared to control boards, due to the sum of two components, the swelling of the wood itself and the release of compression stresses from pressing operation. In the other cases, the percentage of mass loss, on oven-dried basis, was approximately $9 \%$ to both resin contents, without significant differences. The moisture content was between $10 \%$ and $11 \%$, and the thermal treated specimens showed lower water uptake.

In general, reduction in strength and stiffness is the result of elevated temperatures for an extended time. These changes are generally attributed to the thermal degradation of the wood substance. Impact and bending are the most degraded wood properties, whilst bending stiffness and major weight loss are least affected (Yildiz et al, 2002b), and OSB behaves in a similar way.

\section{Biological Properties}

The results of the laboratory decay test ranked the panels into the classes "resistant" and "highly resistant," according to ASTM D 2017-05(2005). The thermal treatment caused a significant decrease in the mass loss for the fungi P. sanguineus and G. trabeum, at 5\% and $8 \%$ resin level, while remaining almost unchanged for G. applanatum and L. lepideus.

Tukey test showed that both thermally treated OSB, with 5\% and $8 \%$ UF resin, exposed to P.sanguineus showed one homogeneous group, which might suggest that a lower resin content treatment may be applied giving the same results. Nevertheless, taking in account the fact that mechanical property results went way up on post-pressing, secondary thermal-treatment, it might be that UF was not totally cured and thus excess urea and formaldehyde were present for non-thermal treated material at 5\% UF resin. It was identified that OSB exposed to G. applanatum showed one homogeneous group, this way both increasing resin content and thermal treatment were not effective to improve the biological resistance. The same result was observed when OSB was exposed to L. lepideus. On the other hand, OSB exposed to G. trabeum and $P$. sanguineus showed two and three homogeneous groups, respectively, thus evidencing that thermal treatment had the same effect as increasing in 3\% the resin content in panels, so an economic study should be carried out to decide which treatment is advisable. Del Menezzi (2004) demonstrated the economic feasibility of this kind of thermal treatment $\left(190^{\circ} \mathrm{C}, 1200 \mathrm{~s} ; 220^{\circ} \mathrm{C}\right.$, $720 \mathrm{~s}$ ) and calculated the rise in the production cost as much as 5\%. OSB with 5\% UF-untreated panels assayed with $G$. trabeum showed only one homogeneous group different from the other treatments. 


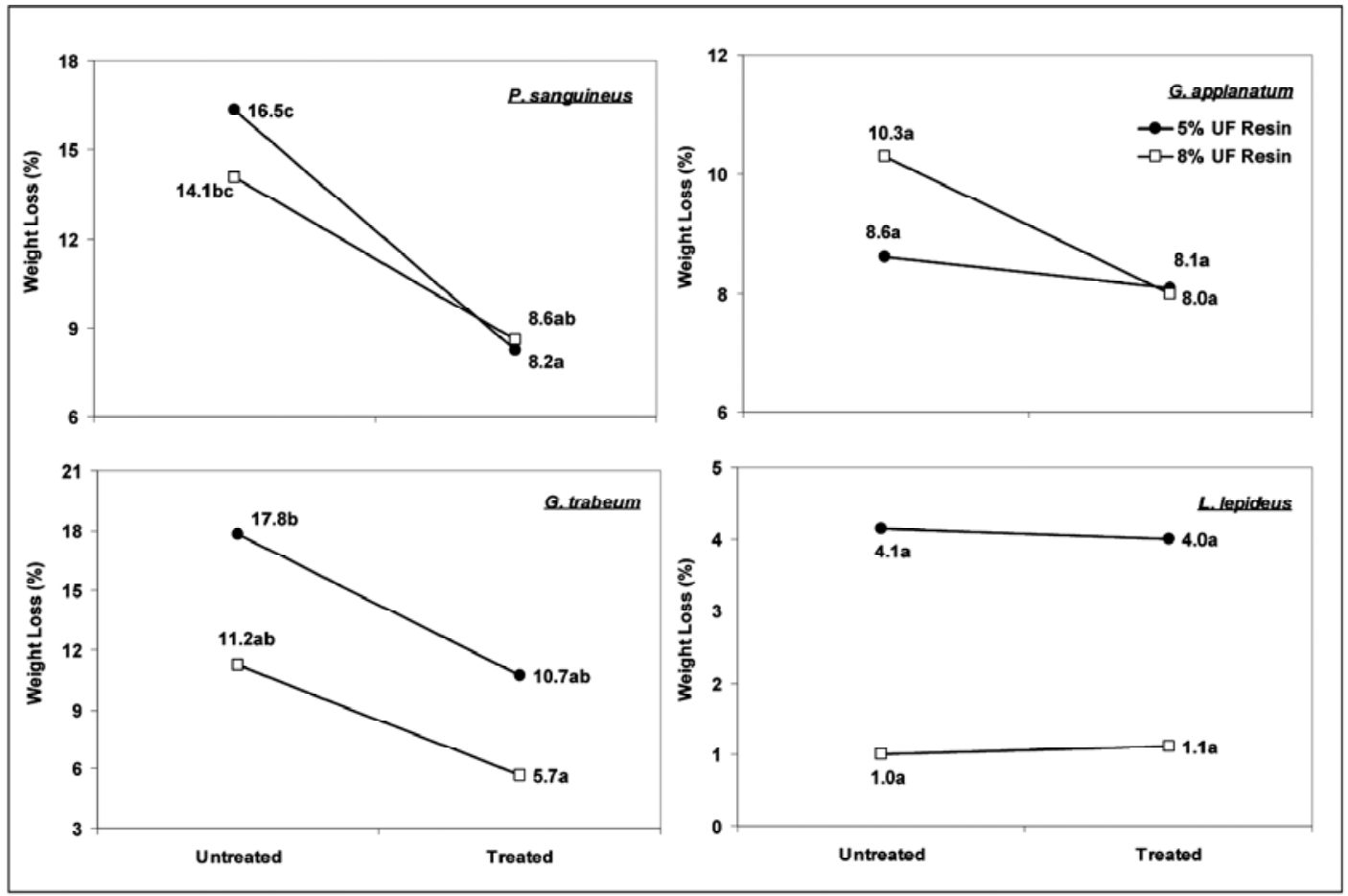

Figure 4: Weight loss of control and thermally treated OSB made from cypress.

Yang et al (2000) found $37.3 \%$ and $49.0 \%$ mass losses on G. applanatum and G. trabeum, respectively, which are 3.6 and 2.8 times higher when compared to the present study; they also obtained a negligible mass loss of just 1.8\% on P. sanguineus. Chung et al cited by Yang et al (2000) stated that structure and design of OSB lead to large voids, which provide abundant paths for fungal hyphae to penetrate and degrade the wood. Therefore, faster and more extensive degradation of OSB was expected. They also verified that in general the brown-rot fungi caused more degradation and greater mass loss than did white-rot fungi, but this statement has not been entirely evidenced in this study. Moreover, the large standard deviations listed by them were in accordance with some aforementioned results of a biological assay, showing the great sensibility and variability of fungi tests. Ayrilmis et al (2005) conducted a decay laboratory test with brown-rot fungus Fomitopsis palustris (Berk. et Curt) Gilbn. \& Ryn and the white-rot fungus Trametes versicolor (L. ex. Fr.) Quel., using 3.5\% PF resin in control aspen OSB, and found $18.77 \%$ and $16.23 \%$ mass loss, respectively. These mass losses are in accordance with the highest mass loss described to 5\% UF resin control OSB. Goroyias and Hale (2002b) treated 3\% PFbonded Scots pine unaligned strandboards $\left(210^{\circ} \mathrm{C}, 320 \mathrm{~s}\right)$ with a $1 \%$ wax content and tested against Coniophora puteana, Postia placenta, Trametes versicolor and Pleurotus ostreatus. The results for the white rot fungi showed little, if any effect of the heat treatment on decay. Heated strandboard $\left(250^{\circ} \mathrm{C}\right.$, 720 s) only achieved $24 \%$ and $20 \%$ reduction in weight loss on C. puteana and P. placenta, respectively. In this study thermal treated $5 \%$ UF strandboards $\left(190^{\circ} \mathrm{C}, 12 \mathrm{~min}\right)$ achieved a reduction of $40 \%$ and $50 \%$ mass loss on G. trabeum and P. sanguineus, respectively, while 8\% UF strandboards showed a reduction of $49 \%$ and $39 \%$, which seems to be a good approach to enhance the panels durability. Again this whole result might be possibly explained by the enhanced UF resin curing that was observed in Figure 1.

It has been shown that thermal treatment causes a strong decrease of the hygroscopicity of the wood and panel, as a result of cross-linking, reduction of hemicellulose content, esterification, the amount of accessible hydroxyl groups and reduction of amorphous regions of cellulose (Tjeerdsma et 
$a l, 2000)$, and since white-rot fungi for their metabolism also are dependent on conversion of hemicellulose, its reduction is believed to be the main cause of the increased resistance against these fungi, mainly on P. sanguineus.

Maritime pine and poplar heat-treated $\left(200\right.$ to $\left.250^{\circ} \mathrm{C}, 6 \mathrm{~h}\right)$ wood showed the presence of polynuclear aromatics hydrocarbons derivatives of phenantrene and acenaphytylene due to degradation of wood constituents. It is most likely that the presence of all such compounds contributes - perhaps to a relatively substantial extent - to the reported resistance of heat-treated timber to fungal and other biological attack (Kamdem et al, 2000). Similar findings correlated to tropolones compounds' natural products found in cypress wood may also difficult the fungi attack.

\section{CONCLUSION}

All mechanical properties of UF resin bonded cypress OSB were higher than the Canadian requirements, except MOE in the parallel direction. Mechanical properties of modulus of rupture, parallel stress at proportional limit, internal bond, screw withdrawal, maximum load, and Janka hardness were not affected by the thermal treatment. Otherwise, the proposed thermal treatment improved all properties related to dimensional stability and it was effective to enhance the durability against three from four fungi evaluated. Dimensional stability was improved in the lower resin level panels. The panels presented good resistance to the tested fungi and were graded as "resistant" or "highly resistant". The higher improvement in susceptibility of the OSB was observed in the decay test of the white-rot fungus $P$. sanguineus in treated panels. Further studies should be focused on determining the critical level of pressing time and resin level.

It is recommended the conduction of a complete research increasing the processing parameters and other types of adhesives.

\section{ACKOWLEDGEMENTS}

Laboratório de Produtos Florestais-LPF/IBAMA thanks the person of Dr. Mário de Andrade from Alba Química Ltda., who supplied the resins, and Mr. Francisco Ozanan C. C. Alencar, Chefe do Departmento de Parques e Jardins da NOVACAP/DF, and Marco Aurélio Silva, who kindly provided the cypress wood. We are in debt to Ms. Theodora Fischli who revised the article. The team also thanks the technicians who collaborated in the execution of this project: Mr. João E. Anacleto, Sérgio Martinez, Luiz D. Santana, Francisco L. de Araújo, Ricardo P. de O. Santos and Dionísio A. do Monte.

\section{REFERENCES}

American National Standard. 1993. Mat-formed wood particleboard: Specification ANSI A208.1. 1993. Gaithersburg: National Particleboard Association. 9p.

American Society for Testing and Materials. 2005. Accelerated laboratory test natural decay resistance of woods. ASTM D2017-05. Philadelphia: ASTM, v.04.09, 2005. (Annual Book of ASTM Standards).

American Society for Testing and Materials. 1991. Standard Test Methods for Evaluating Properties of Wood-Base Fiber and Particle Panel Materials: ASTM D 1037 - 91. Philadelphia: ASTM, v.04.09, 1991. (Annual Book of ASTM Standards). 
American Society for Testing and Materials. 1967. Standard test method for nonvolatile content of urea-formaldehyde resin solutions: ASTM D 1490 - 67. Annual Book of ASTM Standards, Vol. 04.09, American Society for Testing and Materials, Philadelphia, PA.

Ayrilmis, N.; Kartal, SN.; Laufenberg, TL.; Winandy, JE.; White, RH. 2005 Physical and mechanical properties and fire, decay, and termite resistance of treated oriented strandboard. Forest Prod. J., 55(5):74-81

Bengtsson, C.; Jermer, J.; Brem, F. 2002. Bending strength of heat-treated spruce and pine timber. In: Annual Meeting International Research Group on Wood Preservation, Proceedings, 33, Cardiff, Wales, UK, 12 -17 May.

Canadian Standards Association. 1993. OSB and waferboard. Ontario: CSA0437-93, 1993. 18p.

Del Menezzi, CHS. 2004. Estabilidade dimensional por meio do tratamento térmico e seus efeitos sobre as propriedades de painéis de partículas orientadas (OSB). Ph. D. Dissertation on Forest Products Technology and Utilization. UFPR, Curitiba, p 226 (in Portuguese).

Del Menezzi, CHS. Tomaselli, I. 2006. Contact thermal post-treatment of oriented strandboard to improve dimensional stability: A preliminary study. Holz als Roh-Werkst. v. 64, n. 2, p. 212-217.

Goroyias, GJ.; Hale, MD. 2002a. Heat treatment of wood strands for OSB production: Effect on the mechanical properties, water absorption and dimensional stability. In: Annual Meeting International Research Group on Wood Preservation, Proceedings, 33, Cardiff, p 18

Goroyias, GJ.; Hale, MD. 2002b. The effect of high temperature and long pressing time on the dimensional stability and decay resistance of OSB. In: Annual Meeting International Research Group on Wood Preservation, Proceedings, 33, Cardiff, p 20

Hsu, WE.; Schwald, W.; Shields, JA. 1989. Chemical and physical changes required for producing dimensionally stable wood-based composites. Part 2: Heat post-treatment. Wood Sci. Tech. 23(3):281-288

Kallander, B.; Bengesson, C.; Dahlberg, J. 2001. Influence of drying in temperatures between $70^{\circ} \mathrm{C}$ and $120^{\circ} \mathrm{C}$ on selected wood properties of Norway spruce. In: International IUFRO Wood Drying Conference, Proceedings, 7, Tsukuba, p 6

Kamdem, DP.; Pizzi, A.; Triboulot, MC. 2000. Heat-treated timber: potentially toxic byproducts presence and extent of wood cell wall degradation. Holz Roh- Werkst. 58:253-257

Kim, G-H.; Yun, K-E.; Kim, J-J. 1998. Effect of heat treatment on the decay resistance and bending properties of radiata pine sapwood. Material und Organismen 32(2):101-108

Kubojima, Y.; Okano, T.; Ohta, M. 2000. Bending strength and toughness of heat-treated wood. J. Wood Sci. 46(1):8-15

Maloney, TM. 1977. Modern Particleboard and Dry-Process Fiber Board Manufacturing. San Francisco, Miller Freeman. p 672 
Matsumoto, T.; Matsumoto, H.; Fujimoto, N.; Fujimoto, Y.; Murase, Y. 2001. Influence of thermal treatments on the mechanical properties of wood. In: International IUFRO Wood Conference, Proceedings, 7, Tsukuba: p 4

Militz, H. 2002. Thermal treatment of wood: European Processes and their background. In: Annual Meeting International Research Group on Wood Preservation, Proceedings, 33, Cardiff, p 10

Okino, EYA.; Camargos, JAA.; Santana, MAE.; Marques, MHB.; Martins, VA.; Sousa, M de.; Teixeira, DE. 2006. Descrição dos caracteres tecnológicos da madeira de Cupressus glauca Lam. Scientia Forestalis. 72 39-48.

Okino, EYA.; Souza, MR de.; Santana, MAE.; Alves, MV da S.; Sousa, ME de.; Teixeira, DE. 2005. Physico-mechanical properties and decay resistance of Cupressus spp. cement-bonded particleboards Cement \& Concrete Composites 27 333-338.

Okino, EYA.; Souza, MR de.; Santana, MAE.; Alves, MV da S.; Sousa, ME de.; Teixeira, DE. 2004. Evaluation of the physical and biological properties of particleboard and flakeboard made from Cupressus spp. International Biodeterioration \& Biodegradation 53 1-5.

Roffael, E.; Rauch, W. 1973. Einfluß von Temperatur und thermischer Nachbehandlung auf einige physikalische Eigenschaften von diisocyanat-gebundenen Spanplatten. Holz als Roh-Werkst. 31(10):402-405

Shen, KC. 1974. Improving the surface quality of particleboard by high-temperature pressing. Forest Prod. J. 24(10):36-39

Suchsland, O.; Xu, H. 1968. Model analysis of flakeboard variables. Forest Prod. J. 8(8):24-28

Syrjänen, T.; Kangas, E. 2000. Heat-treated timber in Finland. In: Annual Meeting International Research Group on Wood Preservation, Proceedings, 31, Kona, p 9

Tjeerdsma, BF.; Stevens, M.; Militiz, H. 2000. Durability aspects of (hydro)thermal treated wood. In: International Research Group on Wood Preservation, Kona, 31, p 10

Wang, S.; Gu, H.; Neimsuwan, T. 2004 Understanding properties of commercial OSB products. In: Pacific Rim Bio-Based Composites Symposium, Proceedings, 7, Nanjing, 7, p 3

Yang, VW.; Nelson, WJ.; Illman, BL.; Ross, RJ. 2000. Nondestructive Evaluation of Biodegraded Oriented Strandboard: Laboratory Results. In: Annual Conference PATH consortium for wood-frame housing, Proceedings, 2, Madison, 227-230

Yildiz, S.; Çolakoglu, G.; Yildiz, UC.; Gezer, ED.; Temiz, A. 2002a. Effects of heat treatment on modulus of elasticity of beech wood. In: Annual Meeting International Research Group on Wood Preservation, Proceedings, 33, Cardiff, p 6

Yildiz, S. 2002b. Effects of heat treatment on water repellence and anti-swelling efficiency of beech wood. In: Annual Meeting International Research Group on Wood Preservation, Proceedings, 33, Cardiff, p 6 